\title{
Újdonságok a krónikus szívelégtelenség gyógyszeres terápiájában
}

\author{
Nyolczas Noémi dr. \\ Magyar Honvédség Egészségügyi Központ, Kardiológiai Osztály, Budapest
}

\begin{abstract}
A krónikus szívelégtelenség gyógyszeres kezelését illetően számos új vizsgálat eredményét publikálták az elmúlt években, és 2016-ban megjelent az Európai Kardiológiai Társaság (ESC) akut és krónikus szívelégtelenség diagnózisára és terápiájára vonatkozó legújabb irányelve, illetve az amerikai kardiológus társaságoknak (ACC/AHA/HFSA) a szívelégtelenség gyógyszeres kezelésére vonatkozó irányelv megújítása is. A közlemény az új irányelvek tükrében kíván áttekintést adni a krónikus szívelégtelenség gyógyszeres kezelésének aktuális helyzetéról, magába foglalva az új klinikai vizsgálatok eredményeit. Orv. Hetil., 2016, 157(38), 1517-1521.
\end{abstract}

Kulcsszavak: krónikus szívelégtelenség, irányelv, diagnózis, terápia

\section{Novelties in the pharmacological treatment of chronic heart failure}

Recently, results of several novel clinical trials on the pharmacological treatment of chronic heart failure have been published. In addition, the new European Society of Cardiology guidelines for the diagnosis and treatment of acute and chronic heart failure and a focused update by the ACC/AHA/HFSA on new pharmacological therapy for heart failure has been reported in 2016. This paper intends to provide an overview of the current state of the pharmacological treatment of chronic heart failure in the light of the new guidelines which incorporate the results of the new clinical trials.

Keywords: chronic heart failure, guideline, diagnosis, therapy

Nyolczas, N. [Novelties in the pharmacological treatment of chronic heart failure]. Orv. Hetil., 2016, 157(38), 1517-1521.

(Beérkezett: 2016. július 22.; elfogadva: 2016. augusztus 11.)

\section{Rövidítések}

ACC $/$ AHA $/$ HFSA = American College of Cardiology $/$ American Heart Association/Heart Failure Society of America; $\mathrm{ACEi}=\mathrm{ACE}-$ inhibitorok; $\mathrm{ARB}=1$. típusú angiotenzin-II receptorblokkolók; ARNI = angiotenzinreceptor neprilysininhibitorok; $\mathrm{BB}=$ béta-receptor-blokkolók; $\mathrm{BKEF}=$ bal kamrai ejekciós frakció; ESC = European Society of Cardiology; $\mathrm{HFmrEF}=$ heart failure with mid-range ejection fraction; $\mathrm{HFpEF}=$ heart failure with preserved ejection fraction; $\mathrm{HFrEF}=$ heart failure with reduced ejection fraction; MRA = mineralokortikoidreceptor-antagonisták; OAC = orális antikoaguláns; TAG = thrombocytaaggregáció-gátlók

2016 az új szívelégtelenség-irányelvek megjelenésének éve. Május utolsó napjaiban publikálták az Európai Kardiológiai Társaság (ESC) akut és krónikus szívelégtelenség diagnózisára és terápiájára vonatkozó legújabb irány- elvét [1], s vele egy időben jelent meg az amerikai kardiológus társaságoknak (ACC/AHA/HFSA) a szívelégtelenség gyógyszeres kezelésére vonatkozó irányelv megújítása [2] is. Ezen túlmenően az elmúlt években számos, a szívelégtelenség gyógyszeres kezelésére vonatkozó vizsgálat eredménye látott napvilágot. A közlemény az új irányelvek tükrében áttekintést kíván adni a krónikus szívelégtelenség kezelésének aktuális helyzetérôl, magába foglalva az elmúlt években megjelent új vizsgálatok eredményeit is.

\section{A szívelégtelenség új terminológiája}

Már az 1990-es években megjelenő első irányelvek külön kategóriaként foglalkoztak a döntően szisztolés balkamra-diszfunkcióval járó, mai nómenklatúra szerint csökkent ejekciós frakciójú (heart failure with reduced 
ejection fraction - HFrEF), illetve a dominálóan diasztolés diszfunkció okozta vagy megtartott bal kamrai ejekciós frakcióval járó szívelégtelenséggel (heart failure with preserved ejection fraction - HFpEF). A néhány hónappal ezelőtt megjelent új ESC-irányelv [1] bevezetett egy új kategóriát, amit heart failure with mid-range ejection fractionnek (HFmrEF), azaz közepes ejekciós frakcióval járó szívelégtelenségnek nevez. Az új terminológia HFrEF-ról beszél $40 \%$ alatti bal kamrai ejekciós frakció (BKEF) esetén, HFpEF-ról 50\%-os vagy a feletti BKEF mellett és HFmrEF-ről, amennyiben a BKEF 40\% és 50\% közé esik. A HFmrEF egészen biztos nem jelent új patofiziológiai entitást a HFrEF és a HFpEF mellett, inkább egy olyan köztes kategóriát jelöl, amikor a BKEF és az esetek egy részében a diasztolés diszfunkciót jellemző paraméterek sem elegendőek a HFrEF és a HFpEF elkülönítéséhez. Ilyen esetekben a beteg anamnézise, társbetegségei, egyéb klinikai jellemzői, korábbi echokardiográfiás paramétereinek ismerete segíthetnek a betegség típusának elkülönítésében, s ezt követően a megfelelő terápia megválasztásában.

\section{Krónikus szívelégtelenségben szenvedő betegek gyógyszeres kezelése}

A HFrEF-betegek gyógyszeres kezelését vizsgáló tanulmányok döntően $40 \%$ alatti BKEF-ű, míg a HFpEF-vizsgálatok elsősorban $40 \%$ fölötti BKEF-ű betegeket értékeltek. Ezért logikus lenne a gyógyszeres kezelést illetően külön kezelni a HFrEF-betegeket és együttesen a HFpEFés HFmrEF-betegeket. A HFmrEF-betegek kategóriája azonban - bár jelenleg még nagyon keveset tudunk erról a betegcsoportról - meglehetősen heterogénnek tünik; idetartozhatnak a megfelelő terápia mellett jelentős javulást mutató HFrEF-betegek, a dominálóan szisztolés - de enyhe - balkamra-diszfunkcióval bíró esetek, s a dominálóan diasztolés balkamra-diszfunkció mellett - a szokásosnál jelentősebb - szisztolés diszfunkciót mutató esetek. Tekintettel arra, hogy a HFmrEF-betegek vonatkozásában jelenleg egyáltalán nem rendelkezünk evidenciákkal, s az előbb említett heterogenitásból adódóan az idetartozó betegek egy részét feltételezhetően HFrEF-, másik részét HFpEF-betegként kell majd kezelni, jelen közleményben csak a két korábban is definiált betegcsoport, a HFrEF és a HFpEF gyógyszeres kezelésével foglalkozunk.

\section{Csökkent ejekciós frakciójú szivelégtelen (HFrEF) betegek gyógyszeres kezelése}

Az új ESC-irányelv [1] a HFrEF-ben alkalmazott különböző gyógyszeres terápiás lehetőségeket 5 kategóriába sorolja:

- Minden HFrEF-beteg számára javasolt gyógyszeres kezelések.
- Szelektált HFrEF-betegek számára javasolt gyógyszeres kezelések, amelyek kedvező hatása meggyőzően bizonyított.

- Szelektált HFrEF-betegek számára javasolt gyógyszeres kezelések, amelyek kedvező hatása kevésbé bizonyított.

- HFrEF-betegek számára nem javasolt gyógyszeres kezelések, mert kedvező hatásuk nem bizonyított.

- HFrEF-betegek számára nem javasolt gyógyszeres kezelések, mert alkalmazásuk veszélyes lehet.

\section{Minden HFrEF-beteg számára javasolt gyógyszeres kezelés}

A HFrEF kezelésében alkalmazott gyógyszereknek ebben a csoportjában nincs lényeges újdonság. $\mathrm{Az} A C E-$ inbibitorok (ACEi), a béta-receptor-blokkolók (BB) és a mineralokortikoidreceptor-antagonisták (MRA) változatlanul a HFrEF-betegek kezelésének alappillérét képezik. E három gyógyszercsoport minden tagjának valamelyik - lehetőség szerint az irányelvek által javasolt - képviselőjét, a meghatározott céldózisban vagy a beteg által tolerált maximális dózisban minden HFrEF-betegnek kapnia kell, hacsak nem áll fenn a gyógyszer alkalmazását lehetetlenné tévő kontraindikáció vagy intolerancia. Az ESC Heart Failure Long-term Registry [3] adatai alapján ismert, hogy az ACEi-k a betegek 95,4\%-ában, a BB-k a betegek 95,0\%-ában, az MRA-k az irányelvek pontos betartása mellett a betegek 72,4\%-ában alkalmazhatók intolerancia vagy kontraindikáció nélkül. Az előző gyógyszercsoportok hatásosságát HFrEF-ben vizsgáló klinikai tanulmányokból az is ismert, hogy a céldózis minden gyógyszercsoport vonatkozásában a betegek több mint 50\%-ában elérhető.

\section{Szelektált HFrEF-betegek számára javasolt gyógyszeres kezelések, amelyek kedvezö hatása meggyözöen bizonyitott}

Ebbe a terápiás kategóriába olyan gyógyszerek, gyógyszercsoportok tartoznak, amelyek alkalmazásához nem elegendő csupán a HFrEF diagnózisa, hanem egyéb feltételek fennállása is szükséges. Idetartoznak az angiotenzinreceptor neprilysininbibitorok (ARNI), az $\mathrm{I}_{\mathrm{f}}$-csatornablokkoló ivabradin, az 1 . típusú angiotenzin-II receptorblokkolók (ARB), a direkt vasodilatator (bidralazin + izoszorbid dinitrát) kombináció és a diuretikumok.

A kettős hatású $A R N I$-vegyületek - amelyek részben az 1. típusú angiotenzinreceptor szintjén gátolják a renin-angiotenzin-aldoszteron rendszer aktivitását, részben a neutrális endopeptidáz, neprilysin blokkolása révén csökkentik számos endogén fehérje, köztük a natriureticus peptidek biológiailag aktív képviselőinek lebontását - teljesen új gyógyszercsoportot jelentenek a HFrEF kezelésében. Alkalmazásukat a vegyületcsoport LCZ696 (valsartan-sacubitril - Entresto) nevü tagjával végzett PARADIGM HF vizsgálat [4] alapozta meg, 
amely a $2 \times 200 \mathrm{mg}$ LCZ696 hatását hasonlította össze a $2 \times 10 \mathrm{mg}$ enalapril hatásával 8442 NYHA II-IV. súlyosságú, BKEF $\leq 40 \%$, optimális gyógyszeres kezelésben részesülö, emelkedett natriureticuspeptid-szintû HFrEFbetegben. Az LCZ696 20\%-kal (p<0,001) csökkentette a primer végpontként meghatározott cardiovascularis mortalitás és szívelégtelenség miatti hospitalizáció, 20\%kal $(\mathrm{p}<0,001)$ a cardiovascularis mortalitás, 21\%-kal $(\mathrm{p}<0,001)$ a szívelégtelenség miatti hospitalizáció és $16 \%$-kal $(\mathrm{p}<0,001)$ az összmortalitás előfordulási valószínűségét, a HFrEF kezelésében évtizedek óta jól bevált ACEi-hoz, az enalaprilhoz képest. Ez a minden várakozást felülmúló kedvező hatás eredményezte, hogy a vizsgálat eredményeinek 2014 augusztusában történő publikációját követően a szer alkalmazásának feltételes javaslata már megjelent a Kanadai Kardiológus Társaság szívelégtelenségre vonatkozó, 2015 januárjában publikált irányelv megújításában [5], s a szer a 2015. júliusi FDA, majd a 2015. novemberi EMA befogadását követően I. osztályú ajánlásként helyet kapott az új ESCirányelvben [1], s az ACC/AHA/HFSA irányelv megújításában [2] is. Mind az ESC-, mind az ACC/AHA/ HFSA irányelv a PARADIGM HF vizsgálat besorolási és kizárási kritériumait, valamint a vizsgálat felépítését figyelembe véve a következő kritériumok esetén javasolja az ACEi/ARB kezelés LCZ696-ra történő cseréjét: $\mathrm{BKEF} \leq 40 \%$, optimális gyógyszeres kezelés (ACEi/ $\mathrm{ARB}+\mathrm{BB}+\mathrm{MRA}$ ) ellenére panaszos, ambulánsan kezelhető beteg, aki legalább $2 \times 10 \mathrm{mg}$ napi enalaprildózist vagy ezzel ekvivalens dózisú $\mathrm{ACEi}$ - vagy ARB-kezelést tolerál, $B N P \geq 150 \mathrm{pg} / \mathrm{ml}$ vagy $\mathrm{NT}$-proBNP $\geq 600$ $\mathrm{pg} / \mathrm{ml}$ egy éven belül szívelégtelenség miatt kórházi felvételre nem került, illetve $B N P \geq 100 \mathrm{pg} / \mathrm{ml}$ vagy NT-proBNP $\geq 400 \mathrm{pg} / \mathrm{ml}$ egy éven belül szívelégtelenség miatt hospitalizált betegek esetében. Jelenleg kevés adat van az ACEi/ARB kezelésben nem részesülő vagy ezt csak alacsony dózisban toleráló, a többi szer (BB és MRA) vonatkozásában optimálisan kezelt betegcsoportról [6], illetve egyáltalán nincsenek adatok az újonnan diagnosztizált, HFrEF-kezelésben még nem részesülő betegek ARNI-kezeléséról, ezért jelenleg ezekre a betegcsoportokra nem vonatkozik az új irányelvek javaslata. Az indikáció bővítéséhez új adatokra lesz szükség.

Az $\mathrm{I}_{\mathrm{f}}$-csatorna-blokkoló ivabradin már szerepelt az előző, 2012-ben közzétett ESC HF-irányelvben [7], de tekintettel arra, hogy az FDA csak 2015. áprilisban fogadta be a szert, még nem kapott helyet az előző ACCF/ AHA szívelégtelenség-irányelvben [8], így jelenleg új vegyületként jelent meg az ACC/AHA/HFSA irányelv megújításában [2]. Az ivabradin a sinuscsomó pacemakersejtjeiben az $\mathrm{I}_{\mathrm{f}}$-csatorna gátlása révén csökkenti a lassú diasztolés depolarizáció meredekségét, s ezáltal csökkenti a szívfrekvenciát, egyéb lényeges cardiovascularis hatás nélkül. Az ivabradin alkalmazásához szükséges evidenciát a SHIFT vizsgálat [9] szolgáltatta, amely részben ischaemiás, részben nem ischaemiás etiológiájú, az optimális gyógyszeres kezelés (ACEi/ARB és BB) ellenére panaszos és $70 / \mathrm{min}$ vagy a feletti szívfrekvenciájú, 35\% vagy az alatti bal kamrai ejekciós frakciójú, sinusrhythmusban lévő 6558 szívelégtelen betegben értékelte az ivabradin hatását. Az átlagosan 22,9 hónapos követési idő során a randomizált, kettős vak, placebokontrollált vizsgálatban az ivabradin az elsődleges végpont (cardiovascularis halálozás + szívelégtelenség miatti hospitalizáció) szignifikáns csökkenését (HR: 0,82; p<0,0001) eredményezte. Ez a pozitív eredmény döntően a szívelégtelenség miatti hospitalizáció csökkenéséból (HR: 0,$74 ; \mathrm{p}=0,014$ ) adódott, a cardiovascularis mortalitásban (HR: 0,9l; $\mathrm{p}=0,128$ ) nem volt különbség a két csoport között, s a pozitív trend ellenére nem észleltek szignifikáns csökkenést az összmortalitásban (HR: 0,910; $\mathrm{p}=0,092) \mathrm{sem}$. A vizsgálat egyik alcsoport-analízisében [10] a $75 / \mathrm{min}$ vagy annál magasabb szívfrekvenciájú betegek alcsoportjában azonban valamennyi morbiditási és mortalitási végpont vonatkozásában szignifikáns kedvező hatás volt tapasztalható. A SHIFT vizsgálat fontos eredménye az ivabradin kedvező hatásának igazolásán túl az is, hogy bizonyította a szívfrekvencia-csökkentés prognosztikus jelentőségét HFrEF-ben. A SHIFT vizsgálat eredményei alapján mind az ESC-irányelvben [1], mind az ACC/AHA/HFSA irányelv megújításában [2] az ivabradin alkalmazása IIa ajánlásként szerepel, azaz adását meg kell fontolni minden olyan HFrEF-beteg esetében, aki az optimális gyógyszeres kezelés (ACEi/ARB + BB + MRA) ellenére panaszos marad, frekvenciája $\geq 70 / \mathrm{min}$, sinusrhythmusban van és $\mathrm{BKEF} \leq 35 \%$.

$\mathrm{Az} A R B-\mathrm{k}$, a direkt vasodilatatorok és a diuretikumok alkalmazása terén az új ESC-irányelv [1] nem hozott változást, ami nem meglepő, hiszen ezekkel a gyógyszercsoportokkal kapcsolatosan az elmúlt években nem születtek új evidenciák. Az $A R B$-k alkalmazása változatlanul döntően akkor javasolt, ha a beteg az ACEi-kezelést köhögés vagy angioneurotikus oedema miatt nem tolerálja (I. osztályú ajánlás). A diuretikumok alkalmazása a folyadékretenció megszüntetése, illetve a folyadékretenció visszatérésének megelőzése céljából ajánlott a szükséges legalacsonyabb dózisban (I. osztályú ajánlás). A direkt vasodilatator kombináció (bydralazin + izoszorbid dinitrát) alkalmazását az irányelv részben akkor javasolja, ha a beteg mind ACEi-ra, mind ARB-re intoleráns (II/b osztályú ajánlás), részben olyan afroamerikai betegek esetében, akiknek az optimális gyógyszeres kezelés $(\mathrm{ACEi} / \mathrm{ARB}+\mathrm{BB}+\mathrm{MRA})$ ellenére NYHA III-IV. funkcionális osztálynak megfelelő panaszaik maradnak (II/a osztályú ajánlás). Az ESC új terápiás algoritmusa alapján a direkt vasodilatator kombináció alkalmazását rassztól függetlenül is meg lehet fontolni terápiarezisztens szívelégtelenségben.

\section{Szelektált HFrEF-betegek számára javasolt gyógyszeres kezelések, amelyek kedvezo" hatása kevésbé bizonyitott}

A HFrEF-terápiában használatos gyógyszerek közül a digoxin és az N-3 PUFA tartoznak ebbe a csoportba. Új 
evidenciák e szerekkel kapcsolatosan sem láttak napvilágot az elmúlt években, ennek megfelelöen a rájuk vonatkozó ajánlások is változatlanok. A digoxin alkalmazása megfontolható minden olyan sinusrhythmusban lévő HFrEF-beteg esetében, aki az optimális gyógyszeres kezelés (ACEi/ARB + BB + MRA) ellenére panaszos marad (II/b osztályú ajánlás). A digoxin pitvarfibrillációban történő alkalmazásának részletes ismertetése meghaladja ennek a közleménynek a kereteit.

Szintén II/b osztályú ajánlást fogalmaz meg az irányelv az N-3 PUFA (ómega-3 zsírsav) alkalmazását illetően is minden panaszos HFrEF-beteg esetében.

\section{HFrEF-betegek számára nem javasolt gyógyszeres kezelések, mert kedvezö hatásuk nem bizonyitott}

A statinok, az orális antikoagulánsok, a thrombocytaaggregáció-gátlók és a direkt renininbibitorok alkalmazása nem javasolt HFrEF-ben, mivel kedvező hatásuk evidenciákkal nem alátámasztott, viszont e szerek többségének alkalmazása veszélyes mellékhatásokkal járhat.

A statinok (rosuvastatin) hatását két nagy vizsgálat (CORONA [11], GISSI-HF [12]) értékelte HFrEFben. A CORONA vizsgálatban [11] a rosuvastatin ischaemiás etiológiájú HFrEF-ben szignifikánsan csökkentette a cardiovascularis hospitalizációt $(\mathrm{p}<0,001)$, de nem csökkentette sem a mortalitást (HR: 0,95; $\mathrm{p}=0,31)$, sem a coronaria-végpontokat (HR: 0,92; $\mathrm{p}=0,18)$. A GISSI-HF vizsgálat [12], amely részben ischaemiás, részben nem ischaemiás etiológiájú betegekben értékelte a rosuvastatin hatását, sem a mortalitás, sem a morbiditás vonatkozásában nem mutatott kedvező eredményt. Jelenleg a statinok alkalmazását illetően az a szakértői konszenzus, hogy csupán a HFrEF nem indokolja e szerek alkalmazását, azonban azoknál a betegeknél, akik a HFrEF diagnózisa előtt már coronariabetegség vagy hyperlipidaemia miatt statinkezelésben részesültek, a terápia folytatását meg kell fontolni.

$\mathrm{Az}$ orális antikoaguláns (OAC) kezeléssel kapcsolatban szintén nincs egyetlen olyan vizsgálat sem, amely az OAC-kezelés morbiditást vagy mortalitást csökkentő hatását igazolta volna HFrEF-ben akár a placebóval, akár az aszpirinnel szemben. Ezért azokban az esetekben, ahol az OAC-kezelés egyéb indikációja nem áll fenn (például pitvarfibrilláció), a kezelés alkalmazása nem indokolt. A nem K-vitamin-antagonista új OAC (NOAC) -kezelés hatását jelenleg folyó tanulmányok értékelik.

Mivel a thrombocytaaggregáció-gátlók (TAG) vonatkozásában szintén nem rendelkezünk az alkalmazásukat alátámasztó evidenciákkal, a szakértők konszenzusa alapján csupán a HFrEF fennállása miatt nem javasolt alkalmazásuk. TAG-használat csak HFrEF mellett fennálló igazolt érbetegség esetén indokolt.

A direkt renininhibitor aliskirennel végzett vizsgálatok először akut szívelégtelenségben (ASTRONAUT [13]), majd krónikus szisztolés szívelégtelenségben is sikertelennek bizonyultak (ATMOSPHERE [14]). A 2016. áprilisban publikált ATMOSPHERE vizsgálatban [14] sem az aliskiren, sem az enalapril + aliskiren kombináció nem bizonyult noninferiornak az enalaprilhoz képest. Azaz a primer végpont (cardiovascularis mortalitás + szívelégtelenség miatti hospitalizáció) vonatkozásában nemcsak azt nem sikerült bebizonyítani, hogy az aliskiren önmagában vagy az enalaprilhoz hozzáadva effektívebb lenne az enalaprilnál, de az egyenértékűség sem volt igazolható. Az enalapril és az aliskiren együttes alkalmazása pedig szignifikánsan növelte a hyperkalaemia és a vesefunkció-károsodás előfordulását. Mindezek alapján úgy tünik, hogy a direkt renininhibitoroknak nem lesz helye a HFrEF kezelésében.

\section{HFrEF-betegek számára nem javasolt gyógyszeres kezelések, mert alkalmazásuk veszélyes lehet}

A thiazolidindionok (glitazonok), az NSAID-ok és COX2-gátlók, a kalciumantagonisták a 3. generációs dihidropiridinek kivételével, valamint az $A C E i+A R B+M R A$ kombináció alkalmazása bizonyítottan kedvezőtlen hatásaik miatt nem javasoltak HFrEF-ben.

\section{Megtartott ejekciós frakciójú szivelégtelen (HFpEF) betegek gyógyszeres kezelése}

A HFpEF vonatkozásában mind a mai napig nem egyértelmúek a diagnosztikus kritériumok. Az új ESC-irányelv [1] az első, amely a diagnosztikus kritériumok között a szívelégtelenségre jellemző tünetek és panaszok, az LVEF $\geq \mathbf{5 0} \%$ és az echokardiogáfiával meghatározott releváns szívbetegség vagy diasztolés diszfunkció mellett már az emelkedett natriureticuspeptid-szintet is megemlíti. Mindeddig azonban ez utóbbi hiányában és a diasztolés balkamra-diszfunkció meglehetősen komplex meghatározhatósága miatt mind az epidemiológiai vizsgálatokban, mind a klinikai vizsgálatok többségében besorolási kritériumként kizárólag a szívelégtelenségre jellemző tünetek és panaszok, valamint a megtartott BKEF szerepeltek, ami meglehetősen heterogén betegcsoport besorolását jelentette mind a két típusú vizsgálatba. Nagy számban vettek részt bennük tüdőbetegség, obesitas, idős életkor, illetve edzetlenség miatt effort dyspnoét panaszoló betegek tényleges diasztolés diszfunkció, tényleges HFpEF nélkül.

Az eddigi HFpEF-betegcsoportban végzett vizsgálatok (PEP-CHF [15], I-PRESERVE [16], CHARM-Preserved [17], DIG Ancillary [18], SENIORS [19]), amelyek felépítése a fentieknek megfelelően meglehetősen kritizálható, nem eredményeztek szignifikáns rizikócsökkenést a morbiditási, illetve a mortalitási végpontokban. Ennek megfelelően a jelenlegi irányelvek meglehetősen szúkszavúan fogalmaznak a HFpEF-betegek kezelését 
illetően: minden beteg esetében keresni kell a cardiovascularis és nem cardiovascularis társbetegségeket, s ezeket a szakmai irányelveknek megfelelően kell kezelni, valamint diuretikummal kell kezelni a folyadékretenciós betegeket.

A 2014-ben publikált TOPCAT tanulmány [20] volt az első, ahol a bevonási kritériumok között megjelent - legalább opcionálisan - a natriureticuspeptid-szintek meghatározása. A vizsgálat rámutatott arra, hogy a HFpEF diagnosztikájában a $\mathrm{BNP} / \mathrm{NT}$-proBNP szint meghatározásának kiemelkedő jelentősége lehet. A tanulmány a spironolaktonnal kezelt betegcsoportban igazolta a szívelégtelenség miatti hospitalizáció rizikójának szignifikáns csökkenését (HR: 0,83; p<0,04). A natriureticuspeptid-szintek alapján beválogatott betegcsoportban pedig szignifikáns rizikócsökkenést mutatott a szívelégtelenség miatti hospitalizáción túl (HR: 0,64, p = 0,011 ) a primer végpont (a cardiovascularis mortalitás, a szívelégtelenség miatti hospitalizáció és az abortált hirtelen szívhalál) vonatkozásában is (HR: 0,65; p<0,003). Az előbbiek alapján az MRA-kezelés ígéretes terápiás alternatívának tûnik a HFpEF-betegek kezelésében. Ez irányú újabb vizsgálatok előkészítése folyamatban van.

Anyagi támogatás: A közlemény megírása anyagi támogatásban nem részesült.

A szerző a cikk végleges változatát elolvasta és jóváhagyta.

Érdekeltségek: A szerző a SERVIER Hungaria Kft., a NOVARTIS Hungaria Kft., a ROCHE Magyarország Kft. és a KRKA Magyarország Kereskedelmi Kft. tanácsadó testületének tagja.

Az elmúlt három évben előadás(oka)t tartott a következő gyógyszergyártók felkérésére: SERVIER Hungaria Kft., NOVARTIS Hungaria Kft., ROCHE Magyarország Kft., Fresenius Medical Care Magyarország Egészségügyi Kft., Takeda Pharma Kft., Phytotec Hungaria Kft., MSD Pharma Hungary Kft., Bayer Hungaria Kereskedelmi és Szolgáltató Kft.

\section{Irodalom}

[1] Ponikowski, P., Voors, A. A., Anker, S. D., et al.: 2016 ESC Guide lines for the diagnosis and treatment of acute and chronic heart failure. Eur. Heart J., 2016, 37(27), 2129-2200.

[2] Yancy, C. W., Jessup, M., Bozkurt, B., et al.: 2016 ACC/AHA/ HFSA Focused update on new pharmacological therapy for heart failure: An update of the 2013 ACCF/AHA guideline for the management of heart failure. J. Am. Coll. Cardiol., 2016 May 17. pii: S0735-1097(16)33024-8. DOI: 10.1016/j.jacc.2016. 05.011. [Epub ahead of print]

[3] Maggioni, A. P., Anker, S. D., Dablström, U., et al.: Are hospitalized or ambulatory patients with heart failure treated with accordance with European Society of Cardiology guidelines? Evidence from 12440 patients of the ESC Heart Failure Long-term Registry. Eur. J. Heart Fail., 2013, 15(10), 1173-1184.
[4] McMurray, J. J., Packer, M., Desai, A. S., et al.: Angiotensin-ne prilysin inhibition versus enalapril in heart failure. N. Engl. J. Med., 2014, 371(11), 993-1004.

[5] Moe, G. W., Ezekowitz, J. A., O'Meara, E., et al.: The 2014 Canadian Cardiovascular Society Heart Failure Management Guidelines Focus Update: anemia, biomarkers and recent therapeutic trial implications. Can. J. Cardiol., 2015, 31(1), 3-16.

[6] Senni, M., McMurray, J. J., Wachter, R., et al.: Initiating sacubitril/valsartan (LCZ696) in heart failure: results of TITRATION, a double-blind, randomized comparison of two uptitration regimens. Eur. J. Heart Fail., 2016 May 12. DOI: 10.1002/ejhf.548 [Epub ahead of print]

[7] McMurray, J. J., Adamopoulos, S., Anker, S. D., et al.: ESC Guidelines for the diagnosis and treatment of acute and chronic heart failure 2012: The Task Force for the Diagnosis and Treatment of Acute and Chronic Heart Failure 2012 of the European Society of Cardiology. Developed in collaboration with the Heart Failure Association (HFA) of the ESC. Eur. Heart J., 2012, 33(14), 1787-1847.

[8] Yancy, C. W., Jessup, M., Bozkurt, B., et al.: 2013 ACCF/AHA guideline for the management of heart failure: a report of the American College of Cardiology Foundation/American Heart Association Task Force on practice guidelines. Circulation, 2013, 128(16), e240-e327.

[9] Swedberg, K., Komajda, M., Böhm, M., et al.: Ivabradine and outcomes in chronic heart failure (SHIFT): a randomised placebocontrolled study. Lancet, 2010, 376(9744), 875-885.

[10] Böhm, M., Borer, J., Ford, I., et al.: Heart rate at baseline influences the effect of ivabradine on cardiovascular outcomes in chronic heart failure: analysis from the SHIFT study. Clin. Res. Cardiol., 2013, 102(1), 11-22.

[11] Kjekshus, J., Apetrei, E., Barrios, V., et al.: Rosuvastatin in older patients with systolic heart failure. N. Engl. J. Med., 2007, $357(22), 2248-2261$.

[12] GISSI-HF Investigators, Tavazzi, L., Maggioni, A. P., Marchioli, $R$., et al.: Effect of rosuvastatin in patients wirh chronic heart failure (GISSI-HF trial): a randomised, double-blind, placebocontrolled trial. Lancet, 2008, 372(9645), 1231-1239.

[13] Gheorghiade, M., Böhm, M., Greene, S. J., et al.: Effect of aliskiren on postdischarge mortality and heart failure readmissions among patients hospitalized for heart failure: the ASTRONAUT randomized trial. JAMA, 2013, 309(11), 1125-1135.

[14] McMurray, J. J., Krum, H., Abraham, W. T., et al.: Aliskiren, enalapril, or aliskiren and enalapril in heart failure. N. Engl. J. Med., 2016, 374(16), 1521-1532.

[15] Cleland, J. G., Tendera, M., Adamus, J., et al.: The perindopril in elderly people with chronic heart failure (PEP-CHF) study. Eur. Heart J., 2006, 27(19), 2338-2345.

[16] Massie, B. M., Carson, P. E., McMurray, J. J., et al.: Irbesartan in patients with heart failure and preserved ejection fraction. N. Engl. J. Med., 2008, 359(23), 2456-2467.

[17] Yusuf, S., Pfeffer, M. A., Swedberg, K., et al.: Effects of candesar$\tan$ in patients with chronic heart failure and preserved left-ventricular ejection fraction: the CHARM-Preserved Trial. Lancet, 2003, 362(9386), 777-781.

[18] Ahmed, A., Rich, M. W., Fleg, J. L., et al.: Effects of digoxin on morbidity and mortality in diastolic heart failure: the ancillary digitalis investigation group trial. Circulation, 2006, 114(5), 397-403.

[19] Van Veldhuisen, D. J., Cohen-Solal, A., Böhm, M., et al.: Betablockade with nebivolol in elderly heart failure patients with impaired and preserved left ventricular ejection fraction. J. Am. Coll. Cardiol., 2009, 53(23), 2150-2158.

[20] Pitt, B., Pfeffer, M. A., Assmann, S. F., et al.: Spironolactone for heart failure with preserved ejection fraction. N. Engl. J. Med., 2014, 370(15), 1383-1392.

(Nyolczas Noémi dr., Budapest, Róbert Károly krt. 44., 1134 e-mail: nyolczasnoemi@gmail.com) 